Advances in Geosciences, 2, 41-46, 2005

SRef-ID: $1680-7359 /$ adgeo/2005-2-41

European Geosciences Union

(c) 2005 Author(s). This work is licensed

under a Creative Commons License.

\title{
Calibration of a rainfall-runoff model using radar and raingauge data
}

\author{
V. Lopez, F. Napolitano, and F. Russo \\ Department of Hydraulic, Transportations and Roads, University of Rome "La Sapienza", 00184 Rome, Italy \\ Received: 24 October 2004 - Revised: 8 February 2005 - Accepted: 14 March 2005 - Published: 24 March 2005
}

\begin{abstract}
Since raingauges give pointwise measurements the small scale variability of rainfall fields leads to biases on the estimation for the rainfall over the whole basin. In this context meteorological radars have several advantages since a single site is able to obtain coverage over a wide area with high temporal and spatial resolution.

The purpose of this study is to compare the capability of the two different measurement systems in order to give correct input to drive rainfall-runoff models. Therefore a geomorphological model was calibrated, using firstly raingauge data and secondly radar rainfall estimates, for the Treja river basin. In this way it is possible to determine different sets of parameters and the influence of measurement system in hydrological modelling.

The results shown that radar rainfall data is able to improve significantly hydrographs reconstructions.
\end{abstract}

\section{Introduction}

In many hydrological applications, a key factor for accurate flood estimates is to know accurate rainfall input to drive hydrological models. Several raingauges should be installed in different places in order to determine the spatial rainfall distribution due to the evolution of the meteorological phenomena over the selected area (Paoletti, 1993). In fact one of the most important limits of hydrological prediction is due to the low resolution of input of hydrological models (Vaes et al., 2001). This input is given by raingauge measurements so that the accuracy of the output depends essentially on the raingauge network density configuration and on the instrument accuracy (Maheepala et al., 2001). To estimate the rainfall fields over an entire basin raingauge pointwise measurements need to be interpolated and different interpolation methods can lead to significant differences in rainfall field estimates (Dirks et al., 1998).

Correspondence to: F. Napolitano

(francesco.napolitano@uniroma1.it)
Meteorological radars have several advantages since a single site is able to obtain coverage over a wide area with very high temporal and spatial resolution. New meteorological radar systems with better beam resolution, increased signalto noise sensitivity, faster volume scan cycles and dual polarization capability, would allow the progress on radar rainfall estimates (Anagnostou and Krajewski, 1999) and its hydrometeorological applications (Finnerty et al., 1997).

The paper is organized as follows. The Sect. 2 presents the rainfall monitoring system based on the polarimetric Doppler radar Polar 55C located in the South-East of Rome and on raingauge network operating near Treja basin. Then the principal characteristics of the test catchment are briefly described in Sect. 3. Section 4 presents a description of the geomorphological model used in this work, the scheme applied for hydrological losses evaluation and the identification of model parameters. The performance of the WFIUH model, calibrated for the Treja river basin using raingauge data and radar rainfall estimations, are then discussed. In the last section the key results of research are summarized.

\section{Radar and raingauge data at the study site}

Radar and raingauges analyse through fundamentally different processes to estimate rain: raingauges collect water over a period of time, whereas radar obtains instantaneous snapshots of electromagnetic backscatter from rain volumes that are then converted to rainfall via some algorithms.

Spatial and temporal averaging of radar and raingauge data has always been used to reduce the measurement errors and the discrepancy between radar and raingauge estimates. Therefore, extensive analysis of space-time averaging of rainfall over the basin is conducted to study the error structure of the comparison between radar and gauges.

The sampling differences between radar and raingauges give significant uncertainty in rainfall amounts estimations especially when short time intervals are considered: the correlation of the rainfall process increases when the rainfall is 

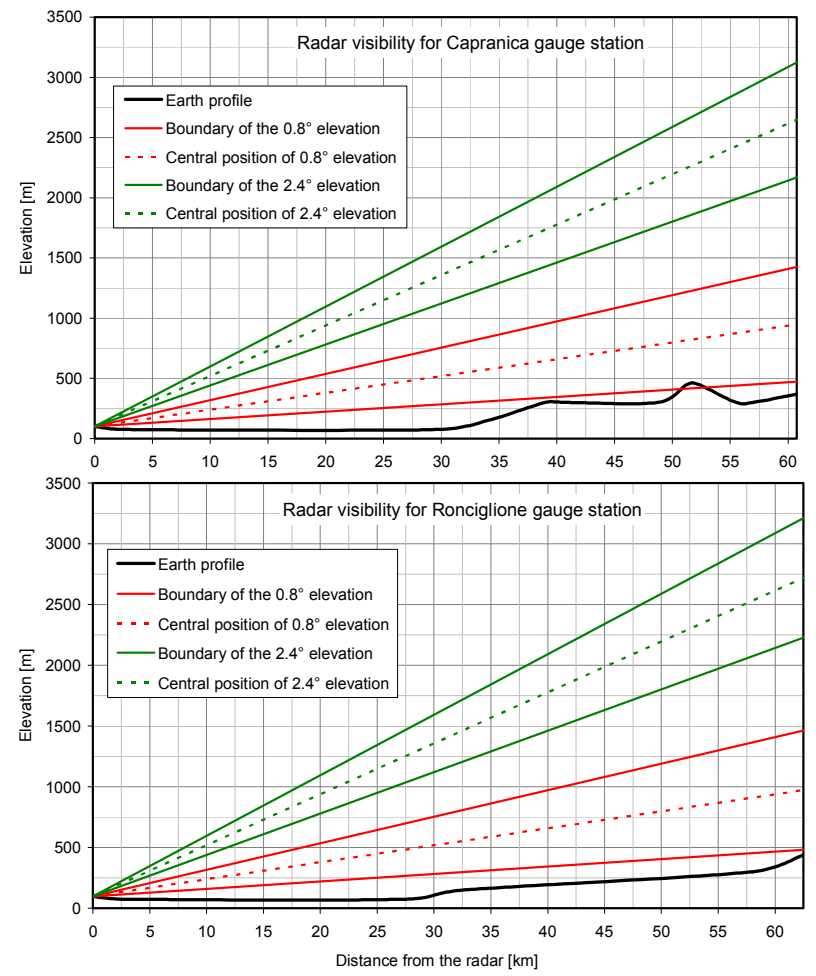

Fig. 1. Profile between the radar and Capranica and Ronciglione raingauge stations. It is shown the Earth profile (black line) the central position of the beam for two different elevation angles (dotted lines) and the beam width for the same elevation angles.

integrated over longer periods (Krajewski, 1995; Steiner et al., 1999).

In the case analysed study raingauge network consists of 5 gauges within the basin and other 11 gauges close Treja river basin. The rainfall accumulation for each raingauge is provided in real time, every $30 \mathrm{~min}$, with a resolution of $0.2 \mathrm{~mm}$.

The raingauge network is integrated with the meteorological radar Polar 55C managed by the Institute of Atmospheric Sciences and Climate of the National Research Council. The Polar $55 \mathrm{C}$ is a C-band $(5.5 \mathrm{GHz}, \lambda=5.4 \mathrm{~cm})$ Doppler dual polarized coherent meteorological radar with polarization agility and with a $0.9^{\circ}$ beam width. The radar is located in the South-East of Rome at a distance of $15 \mathrm{~km}$ from the downtown in the "Tor Vergata" research area $\left(41^{\circ} 50^{\prime} 24^{\prime \prime} \mathrm{N}\right.$, $12^{\circ} 38^{\prime} 50^{\prime \prime} \mathrm{E}, 102 \mathrm{~m} \mathrm{~s} .1$.).

Preliminary analyses on Plan Position Indicators (PPI) collected at different elevations were performed in order to find the best antenna elevation for radar rainfall estimation to monitor the target area. The radar operational elevation angle for precipitation estimation is chosen in such a way that on the average the beam blocking is minimized and at the same time the radar beam does not suffer from melting layer contamination. The operational mode is obtained by compromising between the above two requirements, and it was done over the full $360^{\circ}$ in azimuth at the fixed elevation of $1.6^{\circ}$ (some little differences from this value are due to the strong wind). The absence of non meteorological target in the beam width in the case study area is verified tracking the profile between the radar and several point of the Treja basin (see Fig. 1).

The radar measurements were obtained by integrating 64 sample pairs of the radar returns with a Pulse Repetition Time (PRT) of $0.85 \mathrm{~ms}$. The stored parameters were the reflectivity at horizontal polarization, the differential reflectivity, the mean Doppler velocity, and spectral width.

Several pre-processing data reduction procedures were applied to the radar Polar 55C data (Russo et al., 2005). Firstly, the radar reflectivity was cap at $-10 \mathrm{dBZ}$ to avoid possible noise contamination. Secondly, potential contamination from hail/ice regions was eliminated enforcing an upper limit of $55 \mathrm{dBZ}$ for the reflectivity factor (Aydin et al., 1986). Thirdly, potential ground clutter contamination was removed with by applying algorithm (Russo et al., 2005) that was found in order to filter the radar measurements and it is based on the backscattering signal variance of the differential reflectivity: the meteorological targets have a standard deviation of about $\pm 0.2 \mathrm{dBZ}$ while for ground clutter this value increases significantly with the orographic gradient. In the cells affected by ground clutter the measurements were averaged over the nearest neighbors of $2 \mathrm{~km}$ on either side to reduce the measurement error fluctuations.

To convert the radar data to rainfall rates is used an algorithm based on a Z-R relation. Rainfall values, ranging from 0 to $300 \mathrm{~mm} * \mathrm{~h}^{-1}$, are simulated varying the parameters of the gamma Raindrop Size Distribution (RSD) over a wide range as suggested by Ulbrich (1983). For each RSD the corresponding reflectivity factor, $Z_{h}$, was computed. For $C$-band by means of a non-linear regression analysis the following $Z-R$ relation was obtained:

$R_{Z h}=7.27 \cdot 10^{-2} Z_{h}^{0.62}$

where $Z_{h}$ is the reflectivity factor [dBZ] and $R_{Z h}$ is rainfall $\left[\mathrm{mm} * \mathrm{~h}^{-1}\right]$.

A grid (mesh dimension of $3.0 \times 3.0 \mathrm{~km}$ ) was created over the target area, in such a way that the two rainfall estimations were computed on these cells.

The first method used to estimate rainfall field with the measures of the 16 raingauges available consists on the interpolation of rainfall data using an inverse-distance technique (isohyets method).

The radar estimates are then averaged over its nearest neighbors of $1.5 \mathrm{~km}$, from the central location, either side to obtain averaged measurements.

A time series of radar data was constructed from the instantaneous snapshots of the PPIs and then this time series was interpolated to provide the time synchronization between radar, raingauge and discharge data.

Despite intrinsic problems in the radar and gauge rainfall comparison, raingauges data are used to adjust the radar rainfall estimates. In this work by applying a different technique from the usually applied mean accumulations matching of gauge rainfall and of radar rainfall estimations, at the locations of the raingauges. In this work in fact the adjustment of 


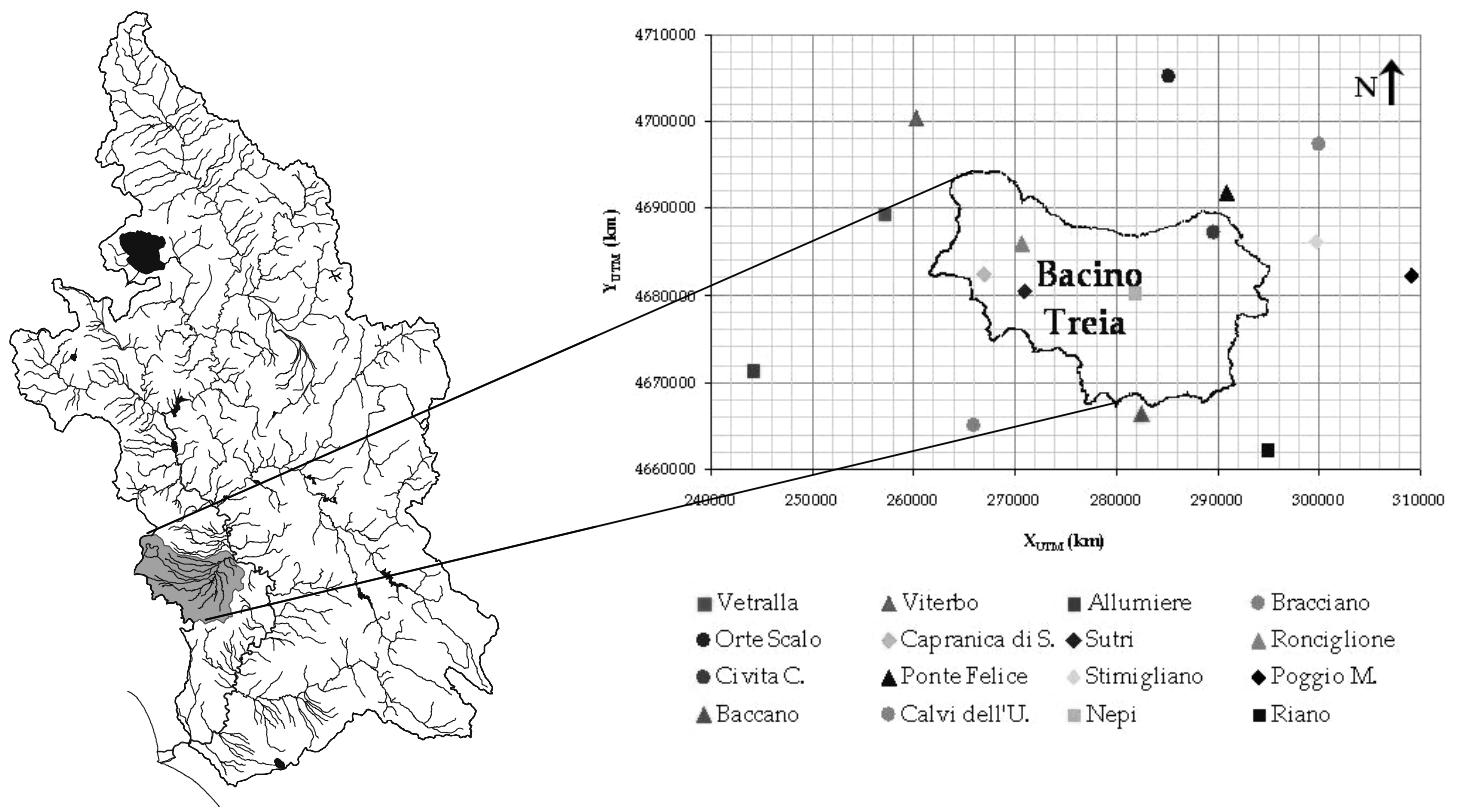

Fig. 2. In the left the Tiber river basin is represented. It is also marked the Treja River that is a right tributary of the Tiber River. On the right the location of Treja river basin and of the raingauge network, insisting on the area, is referred to the radar Polar 55C.

radar data is obtained by the mean accumulations matching of radar rainfall estimations, in the every cell $3 \times 3 \mathrm{~km}$ of the basin, with the gauge rainfall, obtained by interpolation using the inverse distance method. This technique is applied in order to estimate with more accuracy the bias of the radar taking into account the raingauges interpolation method (Russo et al., 2005). When the two estimations of rainfall fields are in average the same, their ratio, the bias of the radar, $\gamma$, is equal to 1 .

\section{Characteristics of the test catchment}

The Treja catchment was used for the flood estimation. The stream flow gauging station is at Civita Castellana, located about $50 \mathrm{~km}$ North of the site of the Polar 55C Doppler radar, with a catchment area of approximately $520 \mathrm{~km}^{2}$. The location of the radar Polar 55C and of the raingauges, distributed throughout the area, is shown in Fig. 2.

The Digital Elevation Model (DEM) and the Digital Terrain Model (DTM) are available for the basin with a pixel resolution of $100 \times 100 \mathrm{~m}$.

To identify the channel network an algorithms that automatically extract the flow directions from cell to cell, from the DEM. The approach applied to model the watershed drainage structure is the eight flow directions D8 (Band, 1986; Tribe, 1992). With this technique each grid cell is directly connected to one, and only one, of its neighbouring cells.

\section{Rainfall - runoff model description}

It is well known that the Instantaneous Unit Hydrograph (IUH) is the probability distribution function of arrival times at an outlet due to a unit impulse into the basin, and that for a Geomorphological Instantaneous Unit Hydrograph (GIUH), the distribution function of arrival times is dependent on the distribution of pathways between the sources and the outlet (Rodriguez-Iturbe et al., 1979; Gupta et al., 1980; Snell et al., 1994). Subsequently we have considered, for the geomorphological description, the width function, that is the frequency distribution of channels with respect to flow distance from the outlet (Mesa et al., 1986; Naden, 1992). This is an approximate representation of the area function under the assumption of a uniform constant of channel maintenance throughout the catchment. The WFIUH is obtained integrating the product of the width function for the geomorphological contribution and the inverse Gaussian density function for the channel hydraulics contribution (Rinaldo et al., 1991; Marani et al., 1991):

$f(t)=\frac{1}{\sqrt{4 \pi D t^{3}}} \sum_{i=1}^{N \max } W F\left(l_{i}\right) l_{i} e^{-\frac{(l i-u t)^{2}}{4 D t}}$

where $W F\left(l_{i}\right)$ are width functions re-scaled with $V_{c}$ (velocity in channel) and $V_{h}$ (velocity in hills), $l_{i}$ is time of $i$-cluster of cells from outlet, $N_{\max }$ is maximum temporal lenght, an $D$ is hydrodynamic dispersion coefficient. In large catchments (greater than $100 \mathrm{~km}^{2}$ ), the travel time across the hill slopes is negligible with respect to the fluvial network so that the density function of travel times, $f(t)$, is:

$f_{(u, D)}(t)=\int_{0}^{L} f_{(u, D)}(t \mid x) W(x) d x$ 
Table 1. Parameters of the WFIUH model for radar and raingauges.

\begin{tabular}{lll}
\hline Parameter & Radar & Raingauges \\
\hline$V_{c}$ & $0.6 \mathrm{~m} / \mathrm{s}$ & $1.0 \mathrm{~m} / \mathrm{s}$ \\
$V_{h}$ & $0.1 \mathrm{~m} / \mathrm{s}$ & $0.2 \mathrm{~m} / \mathrm{s}$ \\
$D$ & $3 \mathrm{~m}^{2} / \mathrm{s}$ & $2.5 \mathrm{~m}^{2} / \mathrm{s}$ \\
\hline
\end{tabular}

where $L$ is the length of the mainstream, $D$ is the hydrodynamic dispersion coefficient and $u$ is the velocity of propagation of the flood wave. $f_{(u, D)}(t \mid x)$ is the PDF of travel time for a path of length $x$ and it may be expressed as:

$$
f_{(u, D)}(t \mid x)=x\left(4 \pi D t^{3}\right)^{-1 / 2} \exp \left[-\frac{(x-u t)^{2}}{4 D t}\right] .
$$

\subsection{Hydrological losses}

In this model the infiltration processes are described by using U.S. Soil Conservation Service (SCS, 1972) model that estimates precipitation excess as a function of cumulative precipitation, soil cover, land use, and antecedent moisture. The keystone of the SCS equations is the soil cover number $C N$, function of soil classification and land use or cover.

The initial $C N$ values are derived from the Corine Land Cover (CLC) project according to the soil land use. Corine Land Cover is a map of the European environmental landscape based on interpretation of satellite images and it was used to estimate the $C N$ over a grid (mesh dimension of $100 \times 100 \mathrm{~m})$. The $C N$ values are then calibrated comparing the $\overline{C N_{\text {Corine }}}$ with the values obtained for each event from the discharge volume. Using data of seven events a mean value of $\overline{C N_{\text {oss }}}$ is estimated, using separately rain obtained by radar and by raingauges. So we can compute the coefficient $\alpha$ given by:

$\alpha=\frac{\overline{C N_{\text {oss }}}}{\overline{C N_{\text {Corine }}}}$.

In this way we find the value $\alpha_{G}=0.991$ for gauges and $\alpha_{R}=0.943$ for radar. This difference, obtained although the rain fields are correctly calibrated, can be attributed to the different ground response at a different spatial and temporal distribution of the rainfall (Faures et al., 1995; Brath et al., 2004).

It is to precise that the events used for the calibration of $\overline{C N_{\text {Corine }}}$ are not referred to heavy rains.

The matrix with the initial values of $C N$ is so corrected multiplying each terms for the $\alpha$ coefficient.

For each event the $\overline{C N_{\text {oss }}}$ depends on the initial moisture conditions so that we assume $C N$ depending on the Antecedent Precipitation Index for thirty days $\left(A P I_{30}\right)$, that is a weighted summation of daily precipitation amounts, and the mean temperature $\left(T_{30}\right)$ for the thirty days antecedent the event. We perform this approach because the simple application of SCS method, with the Antecedent Precipitation Index

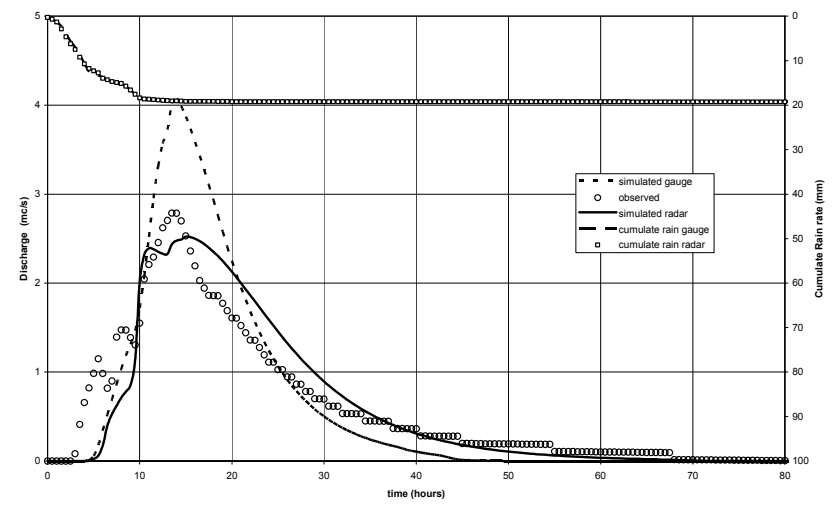

Fig. 3. Observed hydrographs and simulated ones in the Treja river basin for the event of 24 January 2002.

for five days $\left(A P I_{5}\right)$, led for our cases to wrong losses estimation. For this reason we have try to link the moisture conditions of the catchment with both the rain amount of thirty days and the temperatures measured with a gauge located almost in the center of the area (Nepi station). Since the estimation of the API index needs a continuous time registration it is performed using the raingauges network data and so we have the same value for raingauge and radar rainfall.

These parameters are used as index of soil moisture. By a multiple regression, using data of seven events, we find:

$\beta_{R}=0.908+0.005 * A P I_{30}-0.001 * T_{30}$

$\beta_{G}=0.858+0.003 * A P I_{30}-0.001 * T_{30}$

Each term of the matrix is consequently given by:

$C N_{i}=\alpha * \beta_{i} * C N_{\text {Corine }}$

where $i$ is the event indicator, while $\alpha$ and $\beta\left[\mathrm{API}_{30} ; T_{30}\right]$ are different for radar and raingauges.

\subsection{Parameters estimation}

The different precipitation estimated by the two monitoring systems lead to two different sets of model parameters (channel velocity $V_{c}$, hill slope velocity $V_{h}$ coefficient of hydrodynamic dispersion $D$ ). The values of the parameters for radar and for raingauge network are indicated in Table 1.

The values for the two sets are quite different with channel and hill slope velocity for raingauges rainfall about double of the radar rainfall case.

\section{Model performance}

In Fig. 3 the observed hydrographs and simulated ones, for the event of 24 January 2002, are plotted, using the raingauges data and the radar ones. In the Fig. 4 flow-simulated values, for radar and raingauges, are plotted against observed ones. In both Figs. 3-4 the graphs show that the use of the radar leads to calculated flow values more similar to observed ones. 


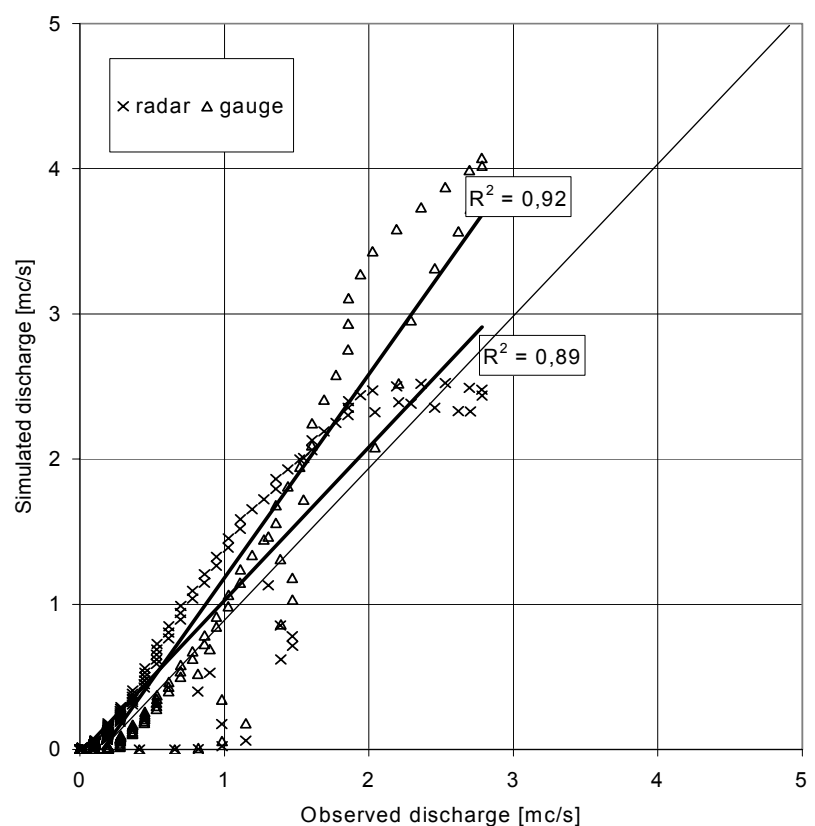

Fig. 4. Scatter plot of the simulated flows (radar and raingauges rainfall) against observed flow (24 January 2002).

Defined also the Mean Absolute Error:

$M A E=\frac{1}{M} \sum_{1}^{M}\left|Q_{s i m}-Q_{o b s}\right|$

the Root Mean Square Error:

$R M S E=\sqrt{\frac{1}{M} \sum_{1}^{M}\left(Q_{s i m}-Q_{o b s}\right)^{2}}$

the Normalized Standard Error:

$N S E=\frac{\sqrt{\frac{1}{M} \sum_{1}^{M}\left(Q_{s i m}-Q_{o b s}\right)^{2}}}{Q_{o b s}}$

and the Peak Error:

$E_{Q}=\frac{\left|Q_{o, c}-Q_{s, c}\right|}{Q_{o, c}}$.

In the Fig. 5 the values of the objective functions are shown for the two different simulations for the event of 24 January 2002: using radar all the indicators give the lowest values.

\section{Conclusions}

Rainfall fields considered as model input were obtained by raingauges data interpolation and by radar estimates: the differences in the rainfall fields estimation have significant consequences both on the parameters linked to the hydrologic losses $(\alpha$ and $\beta)$ and to WFIUH model $\left(V_{c}, V_{h}, D\right)$.

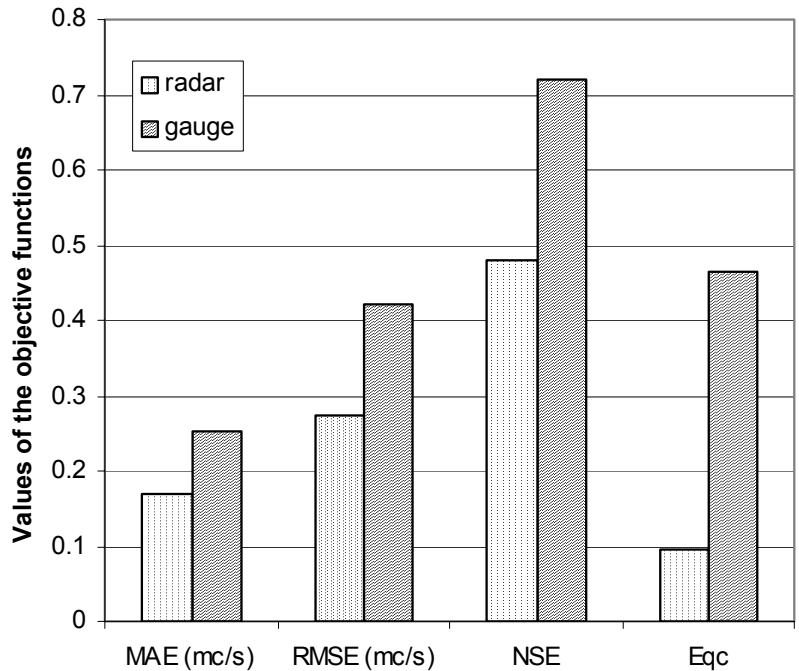

Fig. 5. Values of the objective functions are shown for the two different simulations for the event of 24 January 2002.

It is relevant to note the particular procedure used in this work for the radar data: the adjustment factor is obtained by the mean accumulations matching of radar rainfall estimations, in every cell $(3 \times 3 \mathrm{~km})$ of the basin, with the gauge rainfall, obtained by interpolation using the inverse distance method and not, as usually done, comparing the values just raingauge locations.

In this way two fields are forced to have the same mean even though different spatial and temporal distribution. Furthermore the peculiar interaction with the ground of each rainfall field is held account through the $\alpha$ coefficient. To quantify the performance of the two monitoring systems, with their respectively procedures, they were compared in term of hydrograph, using four objective functions (MAE, $\left.R M S E, N S E, E_{Q}\right)$ : all indicators give better values for radar rainfall fields.

Although the application of the procedure to different case studies is necessary to generalize the work, it is important to observe that the results quantify in a significant way the role of the radar in the rainfall fields estimation and consequentially in the improvement of hydrographs simulation.

Acknowledgements. The authors thank E. Gorgucci of the Climatic and Atmospherical Sciences Institute of National Council of Research for interesting discussions and for providing the radar data. The authors thank also National Hydrographic Service for providing the raingauge and discharge data. This research was supported by National Group for Defence from Hydrogeological Hazards of the National Council of Research (GNDCI-CNR, Italy).

Edited by: L. Ferraris

Reviewed by: anonymous referees 


\section{References}

Anagnostou, E. N. and Krajewski, W. F.: Calibration of the WSR$88 \mathrm{D}$ precipitation processing subsystem, Weather Forecasting, 13, 396-406, 1999.

Aydin, K. T., Seliga, T. A., and Balaji, V.: Remote sensing of hail with dual-linear polarization radar, Journal of Climate and Applied Meteorology, 25, 1475-1484, 1986.

Band, L. E.: Topographic partition of watersheds with digital elevation models, Water Resources Research, 22, 15-24, 1986.

Brath, A., Montanari, M., and Toth, E.: Analysis of the effects of different scenarios of historical data availability on the calibration of a spatially-distributed hydrological model, Journal of Hydrology, 291, 232-253, 2004.

Dirks, K. N., Hay, J. E., Stow, C. D., and Harris D.: High-resolution studies of rainfall on Norfolk Island. Part II: Interpolation of rainfall data, Journal of Hydrology, 208, 187-193, 1998.

Faures, J. M., Goodrich, D. C., Woolhiser, D. A., and Sorooshian, S.: Impact of small-scale spatial rainfall variability on runoff modeling, Journal of Hydrology, 173, 309-326, 1995.

Finnerty, B. D., Smith, M. B., Seo, D. J., Koren, V., and Moglen G.: Space-time scale sensitivity of the Sacramento model to radar-gage precipitation inputs, Journal of Hydrology, 203, 2138, 1997.

Gupta V. K., Waymire, E., and Wang, C. T.: A representation of an instantaneous unit hydrograph from geomorphology, Water Resources Research, 16 (5), 855-862, 1980.

Krajewski, W. F.: Rainfall estimation using weather radar and ground stations, Proceedings of the III International Symposium on Weather Radars, San Paulo, Brazil, 1995.

Maheepala, U. K., Takyi, A. K., and Perera, B. J. C.: Hydrological data monitoring for urban stormwater drainage systems, Journal of Hydrology, 245, 32-47, 2001.

Marani, M., Rigon R., and Rinaldo A.: A note on fractal channel networks, Water Resources Research, 27 (12), 3041-3049, 1991.
Mesa, O. J. and Mifflin, E. R.: On the relative role of hillslope and network geometry in hydrologic response, in: Scale Problems in Hydrology, edited by: Gupta, V. K., Rodriguez-Iturbe, I., and Wood, E. F., chap. 1, 1-17, D, Reidel, Norwell, Mass., 1986.

Naden, P. S.: Spatial variability in flood estimation for large catchments: the exploitation of channel network structure, Journal of Hydrological Sciences, 37 (1), 53-71, 1992.

Paoletti, A.: Effects of rainfall areal distribution on runoff volumes and peak flows, Proceedings U.S.-Italy Bilateral Seminar, Water Resources Publications, 1993.

Rinaldo A., Marani M., and Rigon R.: Geomorphological dispersion, Water Resources Research, 27 (4), 513-525, 1991.

Rodriguez-Iturbe, I. and Valdes, J. B.: The geomorphologic structure of hydrologic response, Water Resources Research, 15 (5), 1409-1420, 1979.

Russo, F., Napolitano, F., and Gorgucci, E.: Rainfall monitoring systems over an urban area: the city of Rome, Hydrological Processes, in press, 2005.

Soil Conservation Service: National engineering handbook, Section 4, Chapter 4-10, Washington, U.S. Department of Agriculture, 1972.

Steiner, M., Smith, J. A., Burges, S. J., Alonso, C. V., and Darden, R. W.: Effect of bias adjustment and rain gauge data quality control on radar rainfall estimation, Water Resources Research, 35 (8), 2487-2503, 1999.

Snell, J. D. and Sivapalan, M.: On the geomorphological dispersion in natural catchments and geomorphological unit hydrograph, Water Resources Research, 30 (7), 2311-2323, 1994.

Tribe, A.: Automated recognition of valley lines and drainage networks from grid digital elevation models: a review and a new method, Journal of Hydrology, 139, 263-293, 1992.

Ulbrich, C. W.: Natural variations in the analytical form of raindrop size distributions, Journal of Climate and Applied Meteorology, 22, 1764-1775, 1983.

Vaes, G., Willems, P., and Berlamont, J.: Rainfall input requirements for hydrological calculations, Urban Water, 3, 107-112, 2001. 